\title{
Chvála snah zaměřených k systematizaci pedagogického vědění: chvála snah profesora Jana Průchy ${ }^{1}$
}

\author{
Tomáš Janík \\ Masarykova univerzita, Pedagogická fakulta, Institut výzkumu školního vzdělávání
}

Hledáme-li u př́ležitosti životních jubileí významných osobností pojmenování pro to, co nejpřiléhavěji vystihuje jejich přínos pro obor, v případě profesora Průchy to nacházíme v jeho vytrvalém úsilí o systematizaci pedagogického vědění a v jeho schopnosti podat dobře uspořádaný, jasný a výstižný výklad kolem klíčových pojmů dané problematiky. To je mimochodem důvodem, proč jsou jeho knihy ve velkém vydávány a prodávány, kupovány a čteny a v neposlední řadě též opisovány.

Celkem snadno lze tudíž dovodit, že chvála snah o systematizaci pedagogického vědění nemůže být u př́ležitosti příslušného jubilea pojata jinak než jako chvála snah profesora Jana Průchy. Nad rámec laudatia adresovaného profesoru Průchovi, jímž je tento text především, se nabízí př́ležitost vyzdvihnout obecně význam slovníkářů a encyklopedistů v našem oboru a zamyslet nad úlohou pedagogických encyklopedií při správě pedagogického vědění a budování poznatkové základny pedagogiky.

Začnu tím, jak já znám profesora Průchu, a to přesto, že nejsem pamětníkem - tedy alespoň prozatím. Předpokládám, že každý, jehož úroveň čtenářské gramotnosti skóruje nad 500 PISA bodů, zažil ten pocit, když objevil autora. Přečtete si první knihu autora $\mathrm{X}$ a začnete pátrat po dalších, až nakonec přečtete celého autora $X$ (platí to ovšem pouze za předpokladu, že autor X nepíše rychleji, než vy čtete). Naposledy se mi to stalo v př́ípadě Jana Průchy.

Nebudu přehánět, když řeknu, že objevení tohoto autora pro mne bylo objevením pedagogiky, a to té, kterou neváhám označit za moderní, jak to ostatně učinil i samotný autor v případě svého stěžejního titulu (Průcha, 1997). Studium díla profesora Průchy mi pomohlo objevit pedagogiku a dovedlo mne k přesvědčení, že pedagogika je jediný pořádný obor ze všech na světě. Jelikož studium díla Jana Průchy nebralo konce, pojal jsem podezření, že

1 Referát byl přednesen na Setkánís prof. Janem Průchou nejen k jubileu jedné knihy: Pedagogická encyklopedie po pěti letech. Dikce mluveného slova je zachována. 
autor je encyklopedistou, což se potvrdilo v okamžiku, kdy nakladatelství Portál vyrukovalo s projektem Pedagogické encyklopedie, v jehož čele nestál nikdo jiný než Jan Průcha.

Jak už to tak bývá, na počátku př́ípravy Pedagogické encyklopedie byl projekt (viz Průcha, 2006). K němu byly zpracovány posudky a vyžádány připomínky z různých stran. Vedle profesorky Milady Rabušicové a profesora Štefana Švece jsem měl možnost jeden z posudků také vypracovat a průběžně se po dobu tří let k celému projektu vyjadřovat, čehož si velmi považuji, nebot' to byla dobrá škola - jedna z nejlepších, které jsem absolvoval.

Nejen v našich posudcích, ale i při prezentacích záměru PEN na různých konferencích (např. na konferenci České asociace pedagogického výzkumu v roce 2007 na PdF JČU v Českých Budějovicích) se koncepce PEN prezentovala a posuzovala na pozadí a v kontextu dřívějších pedagogických encyklopedií vydaných u nás a v zahraničí. $\mathrm{V}$ těchto diskusích se dospělo $\mathrm{k}$ celé řadě postřehů a poznatků, které jsou prozatím $\mathrm{k}$ dispozici jen v podobě šedé literatury, nepočítám-li heslo Pedagogické encyklopedie, slovníky a tezaury, které zpracoval profesor Průcha pro PEN (Průcha, 2009). Rád bych proto využil této př́ležitosti $\mathrm{k}$ tomu, abych některé $\mathrm{z}$ našich postřehů znovu dostal do hry.

Na okraj naší problematiky přičiním čtyři poznámky: první se bude vztahovat $\mathrm{k}$ významu pedagogických encyklopedií při správě pedagogického vědění, druhá se bude vázat $\mathrm{k}$ vývoji encyklopedické tvorby $\mathrm{v}$ pedagogice, třetí bude $\mathrm{k}$ výběru obsahu pro pedagogickou encyklopedii a čtvrtá bude k problému systematizace pedagogického vědění v encyklopediích.

\section{Poznámka první: K významu encyklopedií při správě vědění}

Již na počátku, tj. v roce 2006 bylo zřejmé, že projekt PEN představuje pro českou pedagogiku jedinečnou prŕležitost zachytit a systematizovat stávající pedagogické vědění. Šlo o to, že pedagogika dospěla v průběhu své existence ke značnému množství poznatků teoretické a praktické povahy, které ve svém souhrnu reprezentují dosažený stav pedagogického vědění. Čím dynamičtější nárůst vědění v oboru, tím naléhavější snahy toto vědění dokumentovat, trrídit a syntetizovat tak, aby bylo dostupné $\mathrm{v}$ relativně systematizované podobě.

Snaha o systematizaci pedagogického vědění jde ruku v ruce s úsilím budovat poznatkovou základnu pedagogiky, a to prostřednictvím výzkumu realizovaného různými vědními disciplínami, zaměřeného na různé předmětné 
oblasti situované do různých rovin edukačního systému, přičemž by mělo být produkováno vědění různého typu (srov. Janík, 2010, s. 19). Pod pojmem poznatková základna si můžeme s odkazem na Shulmana (1987, s. 4) představit určitý „kodifikovaný nebo kodifikovatelný agregát poznatků, dovedností, porozumění a technologie, etiky a dispozic i kolektivní odpovědnosti - a současně způsobů, jak je reprezentovat a komunikovat".

Tedy toho je daleko více, než unese papír - byt' tak skvělého typu publikace, jímž je encyklopedie. Přesto lze encyklopedie považovat za jednu z hlavních forem realizace poznatkové základny příslušného oboru. Jde o to, že encyklopedie umožňují spravovat vědění více či méně systematizovaným způsobem a v kombinaci s dalšími formami správy vědění (jako jsou např. slovníky) představují neocenitelný zdroj informací. Ukazuje se, že encyklopedie jsou mnohdy kombinovány se slovníky - znamená to, že jsou zde pospolu k dispozici jak delší hesla v monografickém zpracování, tak stručná vymezení klíčových pojmů (popř. jen synonyma k termínům). Není přitom výjimkou, že součástí je i určitá forma cizojazyčného slovníku. Současný trend vede k lokalizaci encyklopedií a slovníků na internet, kde lze lépe propojovat monografické výklady hesel s jejich definičními výklady a rychleji je aktualizovat či přepracovávat.

\section{Poznámka druhá: K vývoji na poli tvorby pedagogických encyklopedií}

Z pohledu do pedagogických encyklopedií a potažmo lexikonů či slovníků vydaných $\mathrm{v}$ různých jazycích $\mathrm{v}$ různém čase na různých místech je patrné, že daný způsob zpracování pedagogického vědění má úctyhodnou tradici čítající několik staletí. Zatímco v 19. století mají na tvorbu pedagogických encyklopedií relativně velký vliv práce německých a francouzských autorů, ve 20. století získaly na významu encyklopedie napsané $v$ angličtině.

Je celkem pochopitelné, že za zlaté období encyklopedické tvorby v našem oboru lze považovat přelom 19. a 20. století, kdy se pedagogika jako vědní disciplína etabluje na univerzitách a postupně zde získává své katedry. Do práce na pedagogických encyklopediích se velmi produktivně zapojují také čeští autoři - píšící německy (např. Lindner, 1884) a později i česky (Chlup, Kubálek, \& Uher, 1938-1940).

Nejvýznamnějším pokusem zachytit $\mathrm{v}$ mezinárodním měřítku univerzum pedagogického vědění je patrně International Encyclopedia of Education Huséna a Postlethwaite et al. (1985; nejnovější, třetí vydání z roku 2010 pod editorstvím Petersonové, Bakerové a McGawa). Vedle toho jsou vytvářeny 
encyklopedie národní, a to v oborech, které doceňují svoji kulturně-historickou podmíněnost a geografickou situovanost.

Je tomu tak i v případě PEN, která je národní v tom smyslu, že se „1) zaměří prioritně na témata českého školství a vzdělávání, 2) bude vytvořena nejlepšími současnými odborníky z univerzitních a jiných pracovišt' celé ČR“ (Průcha, 2006, s. 2). Důležitý je zde obrat: „národní či mezinárodní v tom smyslu, že..." - jde totiž o to, že v jiném smyslu mezinárodní je International Encyclopedia of National Systems of Education (Postlethwaite et al., 1995), než je tomu např. v př́ípadě díla Interational Encyclopedia of Developmental and Instructional Psychology (Corte \& Weinert et al., 1996).

\section{Poznámka třetí: K problému výběru obsahu pro encyklopedii}

Z pohledu do pedagogických encyklopedií, lexikonů či slovníků je dále patrné, že se uplatňují různá kritéria výběru (pokrytí) pojednávané problematiky. Pokud jde o výběr, a tedy i o záběr, tj. tematické pokrytí, můžeme si povšimnout dvou základních př́istupů, resp. snah: 1) vedle snahy o pokud možno úplné (vyčerpávající) postižení oborové matérie (viz např. Husén \& Postlethwaite et al., 1985/1994) se v poslední době spíše uplatňuje 2) výběrovost a vytvářejí se encyklopedie pro obory pedagogiky (viz např. Corte \& Weinert et al., 1996 za vývojovou a pedagogickou psychologii; Anderson et al., 1995 za pedeutologii; Carnoy et al., 1995 za ekonomii vzdělávání).

Zatímco tvorba vyčerpávajících celo-oborových encyklopedií je reminiscencí na snahu 19. a počátku 20. století pokrýt obor v celé jeho šíri (což bylo mj. mnohdy a mnohde vymezováno prostřednictvím venia legendi, popř. profesury), tvorba úžeji zaměřených encyklopedií pro obory pedagogiky je výrazem specializačního trendu a jde ruku v ruce s narůstající diferenciací předmětu a výzkumného zájmu pedagogiky.

\section{Poznámka čtvrtá: Přístupy k systematizaci (pedagogického) vědění}

$\mathrm{Z}$ pohledu do pedagogických encyklopedií, lexikonů či slovníků je patrné, že se uplatňují různá kritéria strukturování (uspořádání) pojednávané problematiky. Bez nároku na úplnost lze rozlišit šest základních př́stupů k systematizaci pedagogického vědění v encyklopediích:

1. Nesystematizace, alfabetické uspořádání - př́íkladem je Handwörterbuch Pädagogische Psychologie (Rost et al., 2010). 
2. Systematizace dle oborů pedagogiky, ale uvnitř nich již dále nesystematizováno - př́́kladem je Pedagogická encyklopedie on-line nakladatelství $B E L T Z$, kde jsou hesla uvnitř oborů pedagogiky řazena dle data, v němž byla autory napsána (od nejnovějšího po nejstarší).

3. Systematizace dle oborů pedagogiky a uvnitř oborů systematizace dle klíčových tematických okruhů - př́kladem může být Handbook of Sociology of Education (Hallinan et al., 2000).

4. Systematizace dle oborů pedagogiky a uvnitř oborů systematizace dle problémových okruhů - př́kladem je Steindorfova práce (2000) Grundbegriffe des Lehrens und Lernens.

5. Systematizace je podřízena originálnímu (autorskému) konceptuálnímu rámci, který je předpokladem pro vzájemně provázaný výklad oborové matérie - př́kladem je International Encyclopedia of Teaching and Teacher Education (Anderson et al., 1995).

6. Systematizace dle oborů pedagogiky a uvnitř oborů systematizace dle teoretických proudů anebo myšlenkových škol - př́kladem je Kronova práce (1999) s názvem Wissenschaftstheorien für Pädagogen, která v hrubém rozvrhu diferencuje filosofickou a sociálněvědní orientaci pedagogiky a dále pak v jejich rámci různé paradigmatické proudy.

Jak je patrné, od př́ístupu jedna k přístupu šest narůstají nároky na autory a potažmo na čtenáře, zvyšuje se totiž úroveň abstraktnosti při uchopování a tematizaci oborové matérie. Žádný z přístupů přitom nelze označit za královský. Jejich rozlišení je ideálně typické, v praxi tvorby encyklopedií se setkáváme spíše $\mathrm{s}$ kombinacemi než $\mathrm{s}$ čistotou provedení jednotlivého přístupu. Př́́kladem kombinovaného přístupu budiž 25dílná encyklopedie psychologie od nakladatelství Hogrefe. Tento je blízký přístupu, který byl $s$ úspěchem uplatněn $v$ PEN.

\section{Závěrem}

Na PEN se pracovalo tři roky. Psaly se kapitoly, tyto byly následně posuzovány, o PEN se mluvilo na konferencích, autor byl zván na různá fóra, aby ji prezentoval. Svého oficiálního uvedení se PEN dočkala dne 13. ledna 2010 na PedF UK. Nakladatelství Portál na svých webových stránkách při této př́iležitosti publikovalo rozhovor s editorem PEN - prof. Průchou. 
PEN vstoupila do našeho života. Pracuje se s ní, je čtena, excerpována a citována (zpravidla nesprávně, tzn. nikoliv uvedením jmen autorů, nýbrž uvedením jména editora). V odborných časopisech byly publikovány první recenze (Peter Gavora pro Pedagogiku SK, Dominik Dvořák pro PedOr, Martin Kopecký a Michal Šerák pro Andragogickou revue, Jiří Hoskovec pro Československou psychologii). Profesora Gavoru zmiňuji na prvním místě, nebot' jako jeden z mála recenzované dílo uchopil v jeho komplexitě z mnoha různých stran. $V$ těchto recenzních byla PEN s respektem vítána. Oslavoval se její prrínos ve smyslu odkazu budoucím generacím, textu dokumentujícího dobu svého vzniku, textu kanonického, textu užitečného $v$ mnoha ohledech mnohými skupinami uživatelů. $V$ recenzích se přirozeně objevily i připomínky a náměty na doplnění či vylepšení.

Na samotný závěr tedy nezbývá než si položit otázku, jaké výzvy pro vývoj budoucí jsou s PEN spojeny. Omezím se na tři - všechny kontroverzní, avšak vedené dobrým úmyslem.

1. PEN zachycuje primárně empiricko-faktografickou, tedy vědecko-výzkumnou komponentu poznatkové základny, tedy popis toho, co jest, jaké to jest a proč. Vedle toho však do poznatkové základny pedagogiky patřŕ i to, co má být, a to, co dělat - domnívají se někteří (např. Brezinka, 2001, s. 39), jakkoliv jiní s nimi nesouhlasí. At' tak či onak, otevírá se otázka, zda je vůbec možné, aby PEN tyto tři pracovní okruhy pedagogiky, tj. edukologii, filosofii výchovy a praktickou pedagogiku obsáhla, a pokud ano, jakou formou by měla být problematika spadající do filosofie výchovy a do praktické pedagogiky zpracována.

2. V PEN není výrazněji zastoupena diferenciace pohledů dle teoretických přístupů anebo myšlenkových škol. Paradigmatická orientace a vědomí příslušnosti $\mathrm{k}$ určitému teoretickému či metodologickému přístupu lze z kapitol občas vytušit. Otevírá se otázka, zda by tvorba pedagogických encyklopedií neměla být v budoucnosti uchopena jakožto př́ležitost k výkladu diferencovanému dle teoretických př́stupů anebo myšlenkových škol. Cesta prohloubení a diferenciace výkladu dle teoretických přístupů by byla pro obor důležitá, avšak měla by za následek redukci čtenářské obce, čímž by se pedagogická encyklopedie stala projektem nezajímavým z pohledu vydavatele - tím spíše komerčního. Došlo by se asi k tomu, že takto chápaná pedagogická encyklopedie by měla být připravena a vydána péčí „super-pedagogického“ ústavu sdružení Akademie věd a českých univerzit, jenž ovšem neexistuje. 
3. Jako naléhavá se jeví potřeba aktualizování poznatkové základny a potažmo PEN s ohledem na nová zjištění a nové př́stupy. Nelze se ubránit otázce, zda by pro průběžnou aktualizaci nebyla vhodnější elektronická verze „nějaké“ pedagogické encyklopedie, která by byla - volně - dostupná on-line. Domnívám se, že do budoucna je třeba počítat s tím, že komerční nakladatelství se do náročnějších pokusů o dokumentaci a průběžnou aktualizaci pedagogického vědění nebudou hrnout a tyto se stanou doménou univerzitních nakladatelství, ovšem za předpokladu, že se zmobilizují a zmodernizují natolik, aby mohly na tuto výzvu zareagovat. Dost možná půjde také o to, zda najdou „svého profesora Průchu“, který bude ochoten monumentální editorskou práci iniciovat, a zejména dotáhnout do konce (ze zkušenosti víme, že koncovky nám dělají problém...).

Možná jsem závěrem podal na adresu PEN tři nepatřičné komentáře. Jelikož jsou všechny tři směrovány do budoucnosti, nemohou z principu ubrat vůbec nic na zásluhách profesora Průchy, ani na př́nosech PEN - ty jsou zcela mimořádné a je mi ctí a potěšením, že jsem na ně mohl v tomto svém zamyšlení poukázat.

\section{Literatura}

Anderson, L. W. (1995). International encyclopedia of teaching and teacher education. Oxford: Pergamon.

Brezinka, W. (2001). Východiska $k$ poznání výchovy: úvod $k$ základi̊m vědy o výchově, $k$ filozofii výchovy a k praktické pedagogice. Brno: L. Marek.

Carnoy, M. (Ed.). (1995). International encyclopedia of economics of education. Oxford: Pergamon.

Corte, E., \& Weinert, F. (Eds.). (1996). International encyclopedia of developmental and instructional psychology. Oxford: Pergamon.

Hallinan, M. T. (Ed.). (2000). Handbook of sociology of education. New York: Kluwer.

Husén, T., \& Postlethwaite, T. N. (Eds.). (1985). International encyclopedia of education. Oxford: Pergamon.

Chlup, O., Kubálek, J., \& Uher, J. (1938-1940). Pedagogická encyklopedie I-III. Brno: Novina.

Janík, T. (2010). Stav a výhledy českého pedagogického výzkumu. Pedagogická orientace, 20(2), 5-22.

Kron, F. W. (1999). Wissenschaftstheorien für Pädagogen. Stuttgart: UTB.

Lindner, G. A. (1884). Enzyklopädisches Handbuch der Erziehungskunde mit besonderer Berücksichtigung des Volksschulwesens. Wien und Leipzig: Verlag von A. Pichler's Wittwe und Sohn.

Peterson, P., Baker, E., \& McGaw, B. (Eds.). (2010). International encyclopedia of education. Oxford: Elsevier.

Postlethwaite, T. N. (Ed.). (1995). International encyclopedia of national systems of education. Oxford: Pergamon. 
Průcha, J. (1997). Moderní pedagogika. Praha: Portál.

Průcha, J. (2006). Projekt Pedagogická encyklopedie. Praha: Portál.

Průcha, J. (2009). Pedagogické encyklopedie, slovníky a tezaury. In J. Průcha (Ed.), Pedagogická encyklopedie (s. 873-878). Praha: Portál.

Průcha, J. (Ed.). (2009). Pedagogická encyklopedie. Praha: Portál.

Rost, D. H. (Ed.). (2010). Handwörterbuch Pädagogische Psychologie. Weinheim und Basel: Beltz. Shulman, L. S. (1987). Knowledge and teaching. Foundations of the new reform. Harvard Educational Rewiew, 57(1), 1-22.

Steindorf, G. (2000). Grundbegriffe des Lehrerns und Lernens. Bad Heilbrunn: Klinkhardt.

\section{Autor}

doc. PhDr. Tomáš Janík, Ph.D., Masarykova univerzita, Pedagogická fakulta, Institut výzkumu školního vzdělávání, Poříčí 31, 60300 Brno, email: tjanik@ped.muni.cz

Hník, O. (2014). Didaktika literatury: výzvy oboru. Od textů umělecké povahy $k$ didaktice estetickovýchovného oboru. Praha: Karolinum.

Autor monografie zastává názor, že existují tři oblasti, které je třeba mít v oboru didaktiky literatury i školním literárním vzdělávání na zřeteli a které je třeba udržovat v rovnováze, aby obor ani školní předmět neztratily estetické, resp. estetickovýchovné zaměření: 1) četba (četba literárních textů a její reflexe), 2) tvorba (konstrukce a rekonstrukce textu a jejich reflexe), 3) nauka (poznávání kontextů relevantních pro interpretaci textu, udržení kulturní kontinuity a kulturní identity). V současném pojetí literárního vzdělávání stále převládá naukový př́ístup (redukovaný navíc na literární historii a frontální organizační formu výuky). Kniha ukazuje, že je třeba rozvíjet všechny významné oblasti literárního vzdělávání (z nauky např. literární teorii; četbu a tvorbu a jejich reflexi) a jiné př́stupy než (tradičně) naukové, a to především z toho důvodu, že žáci mají rozumět literatuře tak, jak převládá v reálném životě, ve čtenářrství, v kultuře.

Matějek, M. (2014). Dětský svět ve středověku. Ostrava: Moravapress.

Monografie se zabývá postojem západní latinské společnosti k dětství, který se vyvíjel během tisíce let středověku. Dítě našlo centrální místo v křest’anské společnosti. A to nejenom dětství privilegované a štastné, ale také většinové - dětství rolníků, řemeslníků a také chudáků a tuláků vystavených utrpení a násilí ze strany dospělých. $\mathrm{V}$ důsledku silné mortality docházelo k častým proměnám rodiny. Děti často vyrůstaly s nevlastními rodiči. Vlastní rodinu opouštěly také při vstupu do kláštera nebo při odchodu do učení, na studia či na cesty. 